\title{
PENGEMBANGAN ADOPSI INOVASI MELALUI JARINGAN KOMUNIKASI
}

\author{
(Development Of The Innovation Adoption Through Communication Network)
}

\author{
Ellyta $^{1}$, U. Mustakim $Z^{2}$, Rahmatullah Rizieq ${ }^{1}$ \\ ${ }^{1}$ Program Studi Agribisnis, Universitas Panca Bakti Pontianak \\ ${ }^{2}$ Program Studi Manajemen, Universitas Tanjungpura, Pontianak \\ Jalan Kom Yos Sudarso Pontianak \\ Email: el_lyta@yahoo.com
}

Article Submitted : 26-01-2019

Article Accepted : 31-01-2019

\begin{abstract}
Acceleration of innovation adoption can be done if the communication network patterns in farmer groups are known. The research was conducted at The Citrus Production Center in Sambas District, West Kalimantan. Farmer group samples were taken 15 groups randomly while farmer sampling was done with the Representative Sample of Intact System. The structure and role of farmers in communication networks were analyzed by communication network analysis from Rogers and Kincaid and relationship analysis with Rank Spearman method. The results showed the structure of communication, in terms of the level of connectedness of farmers in the group was low while the openness of farmer groups was high. The higher the involvement and openness of farmers in the communication network, the better behavior of farmers in marketing. In addition, the pattern of communication networks that are formed is the pattern of wheels, namely the role of leaders in groups (star) plays an important role in the distribution of information in farmer groups. The other results were efforts to overcome the marketing problems that occur in farmers, namely by delaying the harvest and delay selling.
\end{abstract}

Keyword: Communication Network, Citrus, Delaying Harvest, Delay Selling.

\section{PENDAHULUAN}

Salah satu produk pertanian unggulan Kalimantan Barat adalah jeruk siam. Jeruk dari Kalimantan Barat yang dikenal dengan nama Jeruk Pontianak. Perkembangan luas areal tanam dan produksi selama beberapa tahun terakhir bersifat sangat fluktuatif. Daerah penghasil jeruk siam terbesar di Kalimantan Barat adalah Kabupaten Sambas yang mencapai $90,2 \%$ dari luas areal tanam di Kalimantan Barat (Dinas Pertanian Kalbar, 2006). Namun sesudah tahun 1992, baik luas tanam maupun produksi mengalami penurunan, pada tahun 1999 jeruk Pontianak sudah sulit ditemukan di pasaran serta luasnya kurang dari $1.000 \mathrm{Ha}$. Pemerintah
Kabupaten Sambas mulai menggiatkan kembali penanaman jeruk pada tahun 2006 dimana luas areal tanam jeruk meningkat menjadi 10.998, 16 Ha. (Dinas Pertanian dan Peternakan Kabupaten Sambas, 2006). Pada sekitar awal tahun 2000, tanaman jeruk banyak mengalami serangan hama dan penyakit seperti Fusarium, Diplodia dan penyakit lainnya seperti CVPD. (Dinas Pertanian \& Tanaman Pangan Kalbar, 2003, Azri et al, 2003). Salahsatu jalan keluar dari rendahnya produksi jeruk dan rendahnya harga jual jeruk, Muani (2007) menyarankan untuk menguatkan posisi tawar petani jeruk, sehingga diperlukan penguatan kelembagaan di tingkat kelompok tani, baik dalam hal 
peningkatan produksi, pasca panen dan penguatan kelembagaan pemasaran jeruk.

Penguatan posisi tawar petani erat kaitannya dengan keterlibatan petani dalam kelompoknya. Dalam melakukan usahataninya terjadi interaksi antara satu petani dengan petani lain sebagai anggota masyarakat dan tentu akan melibatkan proses berbagi informasi tentang suatu objek antara petani yang diajak berinteraksi sehingga membentuk jaringan komunikasi di antara petani jeruk. Jaringan komunikasi penting untuk dikembangkan dalam usahatani dan pemasaran jeruk karena dapat memberikan informasi kepada petani tentang harga jual, mutu dan bentuk produk yang diinginkan konsumen dan tujuan pemasaran yang lebih menguntungkan. Saat ini belum ada informasi yang rinci mengenai jaringan komunikasi petani jeruk, baik yang menyangkut keterlibatan atau partisipasi dalam jaringan komunikasi, perolehan informasi maupun faktor-faktor komunikasi yang berhubungan dengan jaringan komunikasi.

Bertitik tolak dari fenomena di atas, maka diperlukan penelitian yang menjawab permasalahan di atas, sehingga dirumuskan masalah penelitian yaitu "Bagaimana peranan jaringan komunikasi yang ada dalam adopsi inovasi pada pemasaran jeruk". Perlunya mengkaji jaringan komunikasi secara mendetil karena dapat diketahui pola dan peran anggota dalam berkomunikasi dan pola serta informasi peran tersebut dapat digunakan dalam proses adopsi dan distribusi informasi.

\section{METODE PENELITIAN}

Penelitian dilakukan menggunakan metode survei. Keluaran yang akan dicapai adalah: (1) Keragaan jaringan komunikasi dan identifikasi peran masing-masing individu dalam sistem; (2) Struktur komunikasi yang dilihat dari hasil analisis dari indeks keterhubungan (connectedness index) dan indeks keterbukaan (oppeness index) pada level individu; (3) Hubungan faktor jaringan komunikasi (variabel bebas) dengan perilaku petani dalam pemasaran jeruk (variabel terikat) yang dilihat dari hasil analisis Rank Spearman.

Metode pengambilan sampel pada penelitian ini dilakukan secara bertahap dengan simple random sampling. Tahap pertama dilakukan pemilihan lokasi penelitian yaitu dari 15 kecamatan penghasil jeruk diambil 5 (lima) kecamatan secara sengaja (purposive) yaitu kecamatan Tebas, Semparuk, Pemangkat, Jawai Selatan dan Teluk Keramat dengan alasan kelima kecamatan tersebut memiliki luas tanam terbesar. Dari kelima kecamatan diambil diambil secara acak 3 (tiga) kelompok tani secara acak sebagai unit penelitian. Selanjutnya dari 15 kelompok tani yang terpilih, seluruh anggota dari kelompok tani tersebut menjadi responden atau informan (Representative Sample of Intact System), sehingga terdapat 374 petani.

\section{Analisis Data}

Dalam penelitian ini teknik analisis data yang digunakan adalah:

1. Analisis sosiogram, yaitu dengan membuat matriks hubungan komunikasi terlebih dahulu yang didapat dari pertanyaan sosiometris yang diajukan dalam kuesioner, selanjutnya hasilnya akan dibuat sosiogram. Analisis jaringan komunikasi dengan cara mengukur struktur komunikasi, yaitu:

2. Tingkat keterhubungan rata-rata hubungan (individual connectedness) antar responden dapat dihitung dengan cara:

$$
\text { Tingkat keterhubungan }=\quad \begin{gathered}
\begin{array}{c}
\text { Jumlah hubungan nyata antar individu } \\
\text { dengan anggota dalam jaringan }
\end{array} \\
\cline { 2 - 2 } \begin{array}{c}
\text { Jumlah hubungan yang mungkin } \\
\text { dalam sistem }
\end{array}
\end{gathered}
$$


Jumlah kemungkinan hubungan dalam sistem dirumuskan: $\frac{\mathrm{N}}{(\mathrm{N}-1)}$

Dimana $\mathrm{N}=$ Jumlah anggota sistem yang ada

Tingkat keterbukaan (system openness index) sistem dalam jaringan komunikasi dapat diketahui dengan cara:

Tingkat keterbukaan $=\quad$ Jumlah hubungan dari anggota sistem yang melintasi batas sistem

Jumlah hubungan yang mungkin di luar sistem

Data mengenai hubungan antara jaringan komunikasi (variabel bebas) dengan perilaku pemasaran petani (variabel tak bebas) dianalisa dengan dengan menggunakan uji Rank Spearman.

\section{HASIL DAN PEMBAHASAN}

\section{Pemasaran Jeruk}

Petani sebagai produsen tidak memiliki kekuatan untuk menentukan harga jual sesuai dengan mutu sehingga mereka berada dalam posisi yang lemah pada saat penentuan harga. Hal ini terjadi karena ketidakseimbangan antara produktivitas dengan pemasaran produk dan membuat petani mulai kehilangan semangat untuk mengusahakan lahan usahatani mereka. Selain itu pada saat penjualan di Tempat Penjualan Jeruk (TPJ) yang menentukan kualitas jeruk menjadi grade $\mathrm{A}, \mathrm{B}, \mathrm{C}$ dan $\mathrm{D}$ adalah TPJ melalui pedagang pengumpul, bukan ditentukan bersama-sama atas dasar kesepakatan bersama petani dan pedagang walaupun sudah ada ketentuan atau syarat dan alat bagi penentuan kualitas jeruk yang dikeluarkan oleh Dinas Pertanian setempat. Penentuan yang dilakukan secara sepihak tentunya akan berdampak kepada rendahnya keuntungan petani secara langsung.

Upaya yang dapat dilakukan dalam rangka meningkatkan mutu dan harga jeruk adalah dengan melakukan tunda panen dan tunda jual. Tunda panen dapat membantu petani dalam meningkatkan kualitas jeruk yaitu dengan menahan jeruk siap panen pada setiap grade selama 2 (dua) minggu tanpa memberikan perlakuan kepada tanaman, akan menyebabkan kenaikan grade satu tingkat dan ini akan menaikkan harga jual. Tunda jual dilakukan dengan tujuan untuk mencari harga jual yang sesuai dengan mempertahankan jeruk tetap berada di pohon sedangkan jeruk sudah siap untuk dipanen walaupun tingkat kemasakan sudah mencapai $80 \%$. Caranya adalah dengan memberikan pupuk Urea dan NPK sekali pemberian sebanyak 400 gram perbatang dengan perbandingan 1:2 maka jeruk dapat bertahan di pohon selama 30 hari.

\section{Hasil Analisis Jaringan Komunikasi Tingkat Keterhubungan}

Sistem yang dimaksud disini adalah kelompok tani dimana responden menjadi anggota di dalamnya. Tingkat keterhubungan rendah paling dominan dalam kelompok tani dengan nilai $0.00-0.40$ yaitu sebanyak 75 responden. Hal ini menunjukkan bahwa keterhubungan responden dalam kelompok tani sangat rendah (Rogers dan Kincaid, 1981). Rendahnya tingkat keterhubungan responden dalam kelompok tani dalam topik pembicaraan pemasaran, karena petani menganggap dengan berbicara kepada sesama anggota kelompok tani tidak akan dapat membantu memecahkan masalah mereka. Karakteristik individu yang memberikan pengaruh kepada keterhubungan responden adalah pengalaman dan kepemilikan alat media massa. Semakin lama mereka berusaha tani 
maka semakin banyak pengalaman mereka dalam berusahatani sehingga menjadi rujukan dan bertanya tempat bagi petani lainnya. Ellyta (2017) mengungkapkan bahwa kepemilikan media massa (dalam penelitian ini adalah telepon seluler) memberikan pengaruh yang sangat besar dalam keterhubungan petani.

Tabel 1. Peranan Responden dalam Jaringan Komunikasi

\begin{tabular}{lcc}
\hline \multicolumn{1}{c}{ Kelompok Tani } & Star & Isolate \\
\hline Kurnia & $1,7,13$ & 9 \\
Tunas tani I & $7,8,10,15,18,20,21$ & 9 \\
Cempaka & $15,18,20$ & $1,4,7,10$ \\
Tani Bahagia & $1,2,3$ & \\
Tani Jaya II & 1,22 & \\
Tani Maju & $2,3,5,17$ & \\
Guntur I & 4,18 & \\
Suka Damai & $1,22,25,30$ & \\
Pembangunan II & 11,15 & \\
Hidup Baru & 15 & \\
Sinar Harapan & $1,6,10$ & \\
Karya Bersama & 22 & \\
Sangkuryang & $3,7,8,9,12$ & \\
Himpunan Karya & 10 & \\
Sumber Jaya & & \\
\hline
\end{tabular}

\section{Tingkat Keterbukaan}

Tingkat keterbukaan merupakan parameter dalam analisis jaringan komunikasi yang dapat digunakan untuk melihat sejauh mana keterbukaan komunikasi suatu jaringan komunikasi terhadap pihak luar. Nilai tingkat keterbukaan yang paling banyak adalah 0.5 yaitu sebanyak 207 orang dan nilai tingkat keterbukaan 1.00 sebanyak 29 orang. Hasil nilai keterbukaan tersebut menunjukkan bahwa sebagian besar atau sebesar 70 persen responden terbuka terhadap pihak di luar kelompok tani. Mereka melakukan interaksi dan berkomunikasi dengan orang-orang di luar kelompok tani. Adapun orang luar yang mereka ajak berkomunikasi adalah Petugas Penyuluh Lapangan, Tempat Penampungan Jeruk (TPJ), anggota kelompok tani lain dan pedagang pengumpul. Keterbukaan anggota kelompok tani kepada pihak di luar kelompoknya dapat mempercepat terjadinya proses adopsi inovasi. Faktor-faktor yang mempengaruhi adopsi inovasi pada tahap kesadaran (awareness) menurut Mardikanto
(1982) yaitu adanya kontak dengan sumber informasi dengan individu dan kelompok dalam masyarakat, tersedianya media komunikasi, adanya kelompok masyarakat, bahasa dan kebudayaan. Didukung oleh penelitian Rangkuti (2009) bahwa makin tinggi tingkat kekompakan dan tingkat keterbukaan makin tinggi pula adopsi inovasi traktor tangan.

\section{Peranan Individu dalam Jaringan Komunikasi}

Hasil sosiogram menunjukkan pola komunikasi berbentuk roda, yang dicirikan adanya peranan responden yang dominan dalam kelompok dan perannya sebagai penyampai informasi. Selain itu sosiogram menunjukkan adanya peran dalam kelompok yaitu star dan isolate. Star dalam kelompok tani bukan hanya timbul akibat peranannya sebagai ketua kelompok tani namun juga peranannya selain sebagai anggota juga sebagai pedagang pengumpul. Rogers dan Kincaid (1981) menyatakan star tidak selalu berhubungan dengan kepemimpinan namun sebagai orang yang paling banyak dihubungi. 
Sejalan dengan penelitian Purnomo (2002) yang menemukan bahwa star ditunjukkan oleh jumlah pilihan terbanyak yang ditujukan pada seorang taruna dari taruna lain yang merupakan anggota jaringan komunikasi.

Pada umumnya terdapat anggapan dari masyarakat bahwa yang berperan sebagai Star dalam kelompok tani adalah ketua kelompok tani. Namun kenyataan yang ada tidak semua ketua kelompok tani berperan sebagai Star, tapi ada pihak-pihak lain yang justru memiliki peranan tersebut. Hal ini dikarenakan pihak tersebut lebih banyak berperan dalam memberikan informasi kepada anggota kelompok tani lainnya dan juga pihak tersebut dijadikan tempat bertanya oleh anggota kelompok, Dalam penelitian ini pihak selain ketua kelompok tani yang berperan sebagai Star adalah pedagang pengumpul (agen), selain menanam dan memproduksi sendiri jeruk, mereka juga membeli dari anggota kelompok tani. Sejalan dengan penelitian Zulkarnaen, et al (2015), Rangkuti (2009), Sulistiawati, et al (2015) yang menyatakan bahwa terdapat peranan anggota yang dominan dalam kelompok yang akan memberikan lebih banyak informasi kepada anggota lainnya.

Muhammad (2004) menyatakan

bahwa hasil analisis jaringan dapat memberikan informasi bentuk hubungan atau koneksi orang-orang dalam organisasi serta kelompok tertentu (klik), keterbukaan satu kelompok dengan kelompok lainnya dan orang-orang yang memegang peranan utama dalam organisasi. Hasil analisis jaringan komunikasi memberikan informasi pola komunikasi yang terjadi, di samping itu memberikan informasi peranan individu dalam kelompok sehingga penangan dalam kelompok akan lebih mudah. Hal ini akan sangat bermanfaat dalam proses adopsi dan difusi inovasi karena star dapat digunakan secara maksimal dalam menyebarluaskan informasi dan dapat digunakan sebagai orang yang membawa dan menerapkan inovasi dalam kelompok tani.

\section{Hubungan Faktor Jaringan Komunikasi dan Perilaku Pemasaran Jeruk}

Faktor jaringan komunikasi dilihat dari dua sub variabel yaitu tingkat keterhubungan dan tingkat keterbukaan sedangkan perilaku pemasaran dilihat dari pengetahuan dan tindakan petani melalui uji Rank Spearman menunjukkan bahwa tingkat keterhubungan mempunyai hubungan nyata dengan pengetahuan dan tingkat keterbukaan mempunyai hubungan nyata dengan tindakan (Tabel 2).

Tabel 2. Hubungan Jaringan Komunikasi dengan Perilaku Pemasaran

\begin{tabular}{lcc}
\hline \multirow{2}{*}{ Jaringan Komunikasi } & \multicolumn{2}{c}{ Perilaku Pemasaran } \\
\cline { 2 - 3 } & Pengetahuan & Tindakan \\
\hline Tingkat Keterhubungan & $0.110^{*}$ & -0.001 \\
Tingkat Keterbukaan & 0.079 & $0.113^{*}$ \\
\hline
\end{tabular}

*) berpengaruh nyata

Semakin banyak petani melakukan komunikasi dengan petani lainnya dalam kelompok tani maka semakin bertambah pengetahuan mereka karena di dalam jaringan komunikasi terjadi proses transfer pengetahuan, belajar, dan berbagi pengalaman. Hutabarat dalam Thirtawati, (2002) menyatakan bahwa pengetahuan merupakan informasi yang diketahui seseorang yang akan diperoleh melalui proses belajar dan pengalaman. Tingkat keterbukaan berhubungan nyata dengan tindakan, artinya semakin terbuka petani terhadap orang-orang di luar sistemnya maka semakin meningkat usaha mereka untuk melakukan tindakan pemasaran. Diseminasi Inovasi Tunda Panen dan Tunda Jual.

Dari informasi pola dan peran komunikasi dari anggota kelompok, dilakukan diseminasi inovasi berupa tunda 
panen dan tunda jual. Diseminasi dilakukan dengan 3 (tiga) cara yaitu penyuluhan dengan menggunakan folder, film, dan tatap muka. Sebaran informasi ini diukur kembali dengan analisis tingkat keterhubungan dengan tujuan untuk melihat sejauh mana diseminasi terjadi dan bagaimana pola komunikasinya. Hasil analisis jaringan komunikasi pada penyebaran pesan inovasi tunda panen dan tunda jual menunjukkan pola komunikasi yang sama yaitu pola roda. Hal ini berarti ketua kelompok tani dan pemimpin informal masih sangat berperan dalam penyebaran informasi. Sejalan dengan pendapat dari Cindoswari (2016), kunci penyebar informasi ini memiliki peranan yang kuat dalam suplai informasi ke dalamm jaringan. Mereka juga berperan sebagai penghubung antara sistem (baca: jaringan komunikasi ekonomi/sosial/ budaya) dengan iklim luar sistem. Tabel 3 berikut memberikan informasi mengenai tingkat keterhubungan responden.

Tabel 3. Tingkat Keterhubungan dalam Diseminasi Inovasi

\begin{tabular}{|c|c|c|}
\hline Nilai & Frekwensi & Persentase $(\%)$ \\
\hline 0.04 & 1 & 1.3 \\
\hline 0.08 & 14 & 18.7 \\
\hline 0.12 & 22 & 29.3 \\
\hline 0.16 & 17 & 22.7 \\
\hline 0.2 & 6 & 8.0 \\
\hline 0.24 & 4 & 5.3 \\
\hline 0.28 & 4 & 5.3 \\
\hline 0.32 & 1 & 1.3 \\
\hline 0.36 & 3 & 4.0 \\
\hline 0.52 & 1 & 1.3 \\
\hline 0.8 & 1 & 1.3 \\
\hline 0.88 & 1 & 1.3 \\
\hline Jumlah & 75 & 100 \\
\hline
\end{tabular}

Terdapat 3 (tiga) orang anggota yang memiliki tingkat keterhubungan di atas 0.5 bahkan dua diantaranya mencapai nilai 0.88 dimana hal ini dapat menjelaskan pentingnya peranan star dalam kelompok.

Selain itu penelitian ini juga menunjukkan tingkat keterhubungan dari anggota dalam hal ini juga rata-ratanya masih rendah yaitu 0.37 dimana hal ini dapat memberikan informasi bahwa pembicaraan tunda panen dan tunda jual masih sedikit dilakukan dalam kelompok. Walaupun sudah disebarkan oleh star tapi informasi yang diterima tidak lagi dibicarakan kepada anggota kelompok yang lain. Hanya sebatas pada penerima informasi pertama.

Dalam rangka akselarasi adopsi inovasi peranan jaringan komunikasi sangat penting untuk diketahui karena dari hal tersebut bisa diketahui pola jaringan dan peranan anggota dalam jaringan. Selain itu dapat diperoleh informasi apakah topik (pesan) komunikasi yang disampaikan menarik atau tidak menarik bagi audien. Kekurangan dan kelebihan dari sistem penyuluhan dapat diperoleh dari analisis jaringan komunikasi sehingga hal ini bisa dijadikan sebagai alat evaluasi dalam penyuluhan.

\section{KESIMPULAN DAN SARAN}

\section{Kesimpulan}

1. Keterhubungan dan keterbukaan petani dalam jaringan komunikasi di dalam kelompok dan interaksinya keluar kelompok serta pengetahuan akan peranan petani dalam kelompoknya, dapat menentukan besarnya peran mereka di dalam proses percepatan adopsi 
inovasi. Keterhubungan antar anggota dalam kelompok tani akan berhubungan dengan pengetahuan petani sedangkan keterbukaan anggota kelompok akan informasi baik dari dalam kelompok maupun luar kelompok tani akan berhubungan dengan tindakan mereka dalam memasarkan jeruk. Terpaan media akan dapat mempengaruhi keterhubungan, keterbukaan dan perilaku petani dalam menerima inovasi yang disampaikan.

2. Model adopsi inovasi dengan memanfaatkan jaringan komunikasi menekankan kepada komunikasi dua arah yang bersinergi dan berkesinambungan dari semua stakeholder yang memiliki perhatian untuk meningkatkan kemampuan kelompok tani jeruk. Jaringan komunikasi memberikan informasi pada saat pengadopsian inovasi antara lain peran-peran anggota kelompok terutama anggota yang dominan karena dari hal tersebut lebih mempersingkat waktu distribusi informasi.

\section{Saran}

Berdasarkan kesimpulan-kesimpulan, maka saran yang dapat diberikan adalah: dengan tingginya derajat keterhubungan dan keterbukaan anggota kelompok maka pemanfaatan media massa perlu dimaksimalkan pada era keterbukaan informasi dalam rangka percepatan adopsi inovasi.

\section{DAFTAR PUSTAKA}

Azri, S.S. Wibowo, M. Hatta dan E.M. Rachmat. S, 2003. Laporan Akhir Pengelolaan Terpadu Kebun Jeruk Sehat. Balai Pengkajian Teknologi Pertanian Kalimantan Barat. Pontianak.

Cindoswari, R.A,. 2016. Analisis Struktur Jaringan Komunikasi dalam Adaptasi Ekonomi Sosial dan Budaya pada Paguyuban Babul Akhirat di Kota
Batam. Jurnal Komunikasi. Vol. X. No. 02.

Dinas Pertanian dan Peternakan Kabupaten Sambas, 2006. Identifikasi Produk dan Potensi Wilayah. Dinas Pertanian dan Peternakan Kabupaten Sambas. Pemerintah Kabupaten Sambas.

Dinas Pertanian Kalimantan Barat, 2006. Agribisnis Jeruk Pontianak. Informasi dan Peluang. Dinas Pertanian Tanaman Pangan Propinsi Kalimantan Barat. Pontianak.

Ellyta, 2017. Jaringan Komunikasi Petani dalam Pemasaran Lidah di Kalimantan Barat. Jurnal Ziraa'ah. Vol. 42 .No. 1.

Mardikanto, T. 1982. Pengantar Penyuluhan Pertanian. Alam Teori dan Praktek. Hapsari. Surakarta.

Muani, A. 2007. Kajian Efisiensi Saluran Pemasaran Jeruk Pontianak dalam Perdagangan Lokal. Jurnal Penelitian Universitas Tanjungpura Pontianak. Pontianak.

Muhammad, A. 2004. Komunikasi Organisasi. Bumi Aksara. Jakarta

Purnomo, M.A. 2002. Hubungan Tipe Diri dengan Jaringan Komunikasi (Kasus Taruna Pesantren Wirausaha Agribisnis Abdurrahman bin Auf di Desa Bulan, Kecamatan Wonosari, Klaten, Jawa Tengah. Skripsi. Bogor: Institut Pertanian Bogor.

Rangkuti, P.A. 2009. Analisis Peranan Jaringan Komunikasi Petani dalam Adopsi Inovasi Traktor Tangan di Kabupaten Cianjur, Jawa Barat. Jurnal Agro Ekonomi, Volume 27 No.1. PSE. litbang. Deptan.go.id 
Rogers, E.M dan L. Kincaid. 1981. Communication Network: Toward A New Paradigm for Research. Collier Macmillan Publisher. London.

Sulistiawati. A, Lubis. D.P., dan Mulyani. E.S. 2014. Analisis Jaringan Sosial Dalam Gabungan Kelompok Tani (Gapoktan) Tani Berkah. Jurnal Sosiologi Pedesaan. Vol. 2, No 2. 2014.
Thirtawati, 2002. Pengetahuan, Sikap dan Tindakan Petani dalam Penggunaan Pestidida (Kasus Petani Sayuran di Desa Sindangjaya, Kecamatan Pacet, Kabupaten Cianjur) Jawa Barat. Skripsi. Bogor: Institut Pertanian Bogor.

Zulkarnan, Lubis D, P. Satria, A, Hubeis, M. 2015. Jaringan Komunikasi dalam Kegiatan Produksi dan Pemasaran pada Pembududaya Ikan di Kabupaten Kampar Riau. Jurnal Sosial Ekonomi Kelautan dan Perikanan. Vol. 10. No.1. 